\title{
Exploring Transnational Marriages among Afghan Refugees in Quetta, Balochistan - Social Forces and Cultural Dynamics
}

\author{
* Syed Kaleem Ullah \\ ** Inam Ullah Leghari (Corresponding Author)
}

\begin{abstract}
Building on ethnographic fieldwork and qualitative techniques, this paper attempts to explore the mechanisms through which refugee populations maintain distinct identities through marriages as a cultural process. An examination of the cultural factors determining marriage choices among Afghan refugees in Quetta reveals how the Afghan diaspora maintains social links between the host and the home country. The cultural practices specific to Afghan refugees describe how cultural forces negotiate the demands of assimilation from the host country while maintaining distinct identities as a diaspora. These practices are framed in the debate about the place of refugees in studies on transnationalism. It comments on how social and cultural factors are equally important in determining the behavior of and towards refugees, contrasting the economic and political focus of most work done on the subject. The current study of Afghan refugees' marriage preference highlights the dynamic nature of notions about migration, imagined Diasporas, and continued connection to homeland even after generations of exile in the host country which is Pakistan.
\end{abstract}

Keywords: Transnational Marriages, Cultural Determinants, Afghan Diaspora, Quetta Baluchistan Introduction

Within the emerging literature and research on transnationalism, the focus on refugee groups and exile communities remains marginal, with a few exceptions (Basch et al., 1994; Landolt et al., 1999). The existing literature on exile communities and refugee groups has rarely focused to include the broader non-political implications of transnational activities'(Al-Ali, Black, \& Koser, 2001) Studies on transnationalism have mainly focused on the economic dimensions of migrants, with refugees being studied largely in a political context. Research on international migration has distinguished between labor migrants and refugee groups, refugees being the focus of political facets, and migrants the economic aspects 'of global systems and interactions' (ibid). This exclusion of refugees results from a previous perspective and trend in global migration studies which focused primarily on labor migrants (Vertovec \& Cohen 1999). Refugees are generally treated as a 'transient' phenomenon, arising from a "rooted, stable" conception of society, in which the mobility of refugees becomes an anomalous occurrence (Stein \&Tomasi, 1981).

Bach et. al (1994, p.7) define transnationalism as "the process by which immigrants forge and sustain simultaneous multi-standard social relations that link together their societies of origin and settlement". In this way, Schiller, Basch, and Szanton-Blanc (1995, p.49) have showed that transnationalism contributes to diminishing the 'significance of national boundaries' in the flow of culture, people and ideas.

Transnational perspective helps to understand several social, economic, and political phenomena affected by global processes. Transnational migration as an area of study has revealed insights into processes through which the migrant communities interact with an existing society's institutions, development of migration policies, access, and discrimination in civil society, as well as the economic and emotional hardships that migrants go through (Kivisto, 2001). The implied assumption in much anthropological writing is that transnationalism has replaced assimilation. However, in this age of globalization, migrants and refugees tend to have a double attachment with host and home countries. These differentiated relationships and attachments are described as transnational connections.

In an age where nation-state building processes are playing an important role in cultural and political spheres, and globalized economies work towards weakening the role of borders,

Department of Anthropology, Quaid-i-Azam University, Islamabad

** Department of Anthropology, Quaid-i-Azam University, Islamabad Email: inam.leghari@qau.edu.pk 
'transnational migration is playing a complex, significant, yet little-noted role' (Miles, 1993: 27). Migrants may adopt varying strategies for different aspects of their life. They might integrate in language yet maintain a distinct identity through cultural traditions. Integration cannot be understood as a homogenous, linear process. The experience of integration varies from person to person and might be different with age, social and economic status. Thus, migrants may be economically wellintegrated but poorly in social aspects (Fletcher, 1999).

Transnationalism has implications for 'activities and relationships within households and families. In this research, the focus is on transnational matrimonial alliances among Afghan refugees living in Quetta, Pakistan. It studies the factors taken into consideration in the selection of a spouse among the Afghan diaspora population. Several non-governmental and governmental organizations studied the relationship between migration, transnationalism, and marriage and explored two types of marriages among migrants, transnational endogamy and intermarriages and marrying in the host country. Transnational endogamy is a prevalent marriage pattern among refugees, which has also been called 'family forming migration'. This involves the 'introduction' or 'importing' a marriage partner from the home country (Gernsheim, 2007).

This article describes how the Afghan diaspora living in Quetta, Baluchistan prefer to have transnational marriages to those spouses that belong to their country of origin. Building on Glick Schiller and Levett's (2004) ideas, this article describes the transnational marriages of Afghan diaspora in Quetta, Baluchistan - how they position themselves in the host society through their "ways of being" in the host country, and "ways of belonging" to the country of origin. According to Levitt and Glick Schiller, the migrants display their 'belonging' consciously and concretely (2004). These conscious actions are determined through a sense of 'collective identity'. In contrast, the behaviors adopted by the refugees rather than their identities, determine their 'ways of being' in the host country. These behavior patterns establish a unique cross-border existential space, which operates in social and cultural dimensions (Levitt and Schiller, 2004). This interlinked space that transect national and cultural boundaries is referred to as a 'transnational social field'.

Cultural concepts that predominantly determine transnational marriage choice for Afghans are also discussed in this paper. We also show how cultural factors influence individuals' choices and through different processes that rationalize these choices to its practitioners that lead to cross border connections. Social practices of displaced groups trace roots to their country of origin and are practice in close resemblance to their original settings. Afghan refugee marriage patterns illustrate this trend of how after decades of exile (in some cases after 3rd or 4th generations), they trace their roots to country-of-origin Afghanistan, which never ends the sense of returning to their homeland. The practice of transnational marriages may strengthen social cohesion to the place of origin, as through transnational marriage alliances these Afghan refugees link themselves with their country of origin. These transnational marriages may link different tribes of Afghan refugees bringing peace, solidarity, and social cohesion among warring tribes. Transnational marriages may limit the integration and assimilation of refugees in host society as well.

The current paper describes transnational marriages of the Afghan diaspora in Quetta, Baluchistan, and the factors contributing to these marriages.

\section{Profile of Afghan Diaspora in Pakistan}

A major exodus of Afghan refugees was experienced by Pakistan when millions of Afghans fled their homeland, after the 1979 soviet invasion of Afghanistan. The fear of executions on religious, ethnic, political, etc. led to a massive exchange of Afghans from their country of origin. The largest migration of Afghan refugees into Pakistan occurred in 1979 and 1980. During this period, over 1.5 million Afghans came to Pakistan seeking refuge from the violence, instability, and chaos that was affecting the country. In 1988 and 1990 two more waves of migration came into Pakistan, with the rise of the Taliban after the Soviet withdrawal. Over the period, more ethnic minorities started to migrate from Afghanistan as the Pashtun-dominated Taliban regime started to persecute these minorities.

A census of Afghan refugees residing in four provinces of Pakistan was conducted in 2005 which describes the clearest picture regarding residential patterns and the number of Afghan refugees in Pakistan. The census showed several registered 3,049,368 Afghan refugees residing in 548,105 households across Pakistan. This census counted those Afghans arriving in Pakistan after 1 December 1979, with those having Pakistan Validity Card or having a Pakistan Identity Card not being counted in. The census clearly showed that Pakistan's North-West Frontier Province (NWFP) had the biggest 
chunk of Afghan refugees numbering $(61.6 \% ; 1,878,170)$ followed by Baluchistan province $(25.2 \%$; $769,268)$, Punjab and Sindh provinces with $(6.8 \% ; 207,758),(4.5 \% ; 135,734)$ respectively. It also showed that in Islamabad $(1.5 \%$; 45,259) Afghan refugees were residing while Kashmir had $(0.4 \%$; 13,079) refugees (see for details Government of Pakistan and UNHCR, 2005). This census also showed '1.29 million (42.3\%) lived in refugee camps. The rest of 1.75 million (57.7\%) had settled in rural and urban areas around Pakistan (Ibid, 2005); (International Organization for Migration Afghanistan, 2014).

If we see the ethnic composition of Afghan diaspora in Pakistan, most of them belong to Pashtuns ethnicity and is followers of Sunni Islam, who are settled on both side of the border and huge movement of people, to and fro, takes places on daily basis. There are also a significant number of Afghans belonging to other ethnic groups like Tajiks, Hazards, Baloch, and Uzbeks, present in Pakistan. In the Pakistani job market, members of the Afghan diaspora are mostly working as unskilled manual labor having low wages in the informal sectors of the economy such as construction work, manual jobs, agriculture, carpet weaving sector, business and trade, transportation, waste collection and recycling, etc. These are kind of jobs which have long hours and social isolation. (Elaheh Rostami-Povey, 2007). There are cases of second and third-generation refugees who were born here and have lived in Pakistan for more than three decades, but they all still are described as 'Muhajir' from the mainstream Pakistani population which means refugee.

Characteristic features of Afghan refugees' social organization present a typical form of Afghan culture. Kor O Kahol (house), Tarboor (Patrilineal Cousin), Kheil (Tribe), Kaum or Qaum (Clan) are some of the dominant features of Afghan refugees' social organizations. Being patriarchal society role of women is limited in social setup, particularly outside the house. Women are considered as the pride and honor of a man.

\section{Setting the scene}

The ethnographic fieldwork for this study was conducted in the 'Nawan Killi' settlement on the outskirts of Quetta, the capital of Baluchistan. The word 'Nawan Killi' is derived from two words of the Pashtu language, local term for it is, 'Nawan' (means new) and 'Killi' (means village.) This area became prominent since the 1980s when a huge number of Afghan refugees migrated; the name was put then as 'Nawan Killi' (new village) as those who migrated recently to this city settled in this village. It is located approximately $5 \mathrm{~km}$ North-West from the main city and a densely populated area. Different Afghan ethnic groups are living in this area. The majority of these ethnic groups are Pashtun. Pashtun sub-tribe such as Hotak, Tokhi, Kandhari, Kochi, Sulemankheil, Tarakai etc. are in majority in this area.

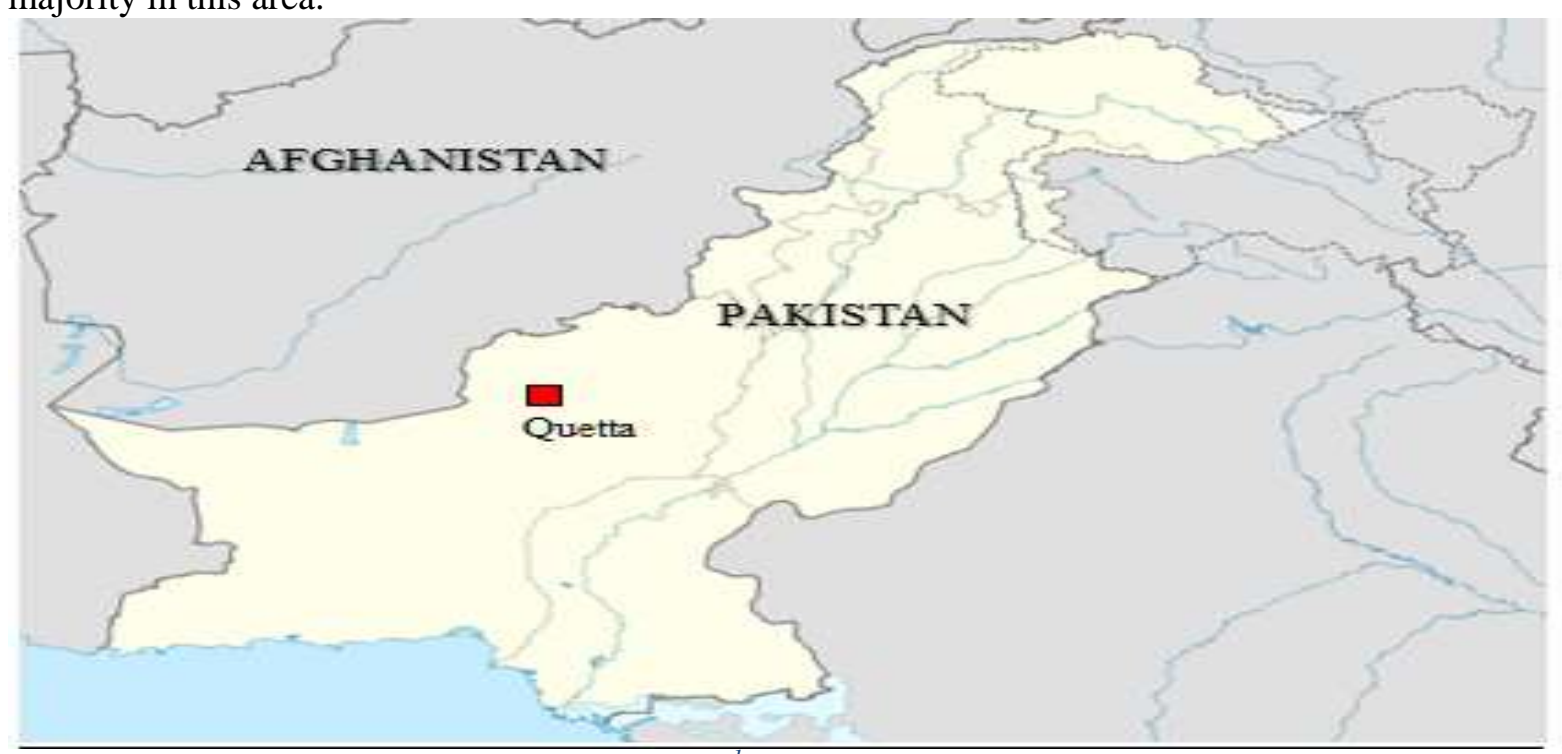

\section{Methodology}

Figure 1. Map showing Quetta

The research is based on qualitative research design and it uses ethnographic methods. Using anthropological methodology, this research was conducted to understand transnational marriages of

${ }^{1}$ Source: Wikipedia (used under Creative Commons License) 
Afghan refugees. The sample for the current study consisted of 60 respondents ascertained through using the purposive sampling technique. Key informants, participant observation, in-depth interviews, case study method, and Focus group discussions were conducted to collect data. Data was analyzed through thematic analysis. To keep the anonymity and privacy of respondents, pseudo-names are used in this paper. Other ethical considerations like informed consent were also followed during the whole process of research.

\section{Findings}

\section{Cultural Concepts of Afghans about Marriage Practices}

To understand the transnational marriage patterns among the Afghan diaspora, it is necessary to discuss the following cultural concepts which play a vital role for Afghan refugees while deciding marriage preferences.

\section{The concept of Paighor (mocking or criticizing)}

An aspect of undesired marriages with locals is the concept of Paighor in Pashtun culture. The word Paighor means 'taunt' or 'mock' or 'tease', of an individual due to his/her certain act. The word Paighor carries a deeper sense in Pashtun and Afghan culture. It is implied to various acts and works as a controlling mechanism in the tribal society. Socially undesirable and tabooed acts are eliminated through the concept of Paighor. The fear of bringing Paighor, because of a certain act, restricts individual not to perform that act. The concept of Paighor has a sense of undesirability and socially unapproved act for an individual. So, this concept of Paighor becomes a controlling mechanism of certain acts in society.

The concept of Paighor also has a prominent role in marriage preferences, particularly that of local marriages. For those who perform marriages with local Pakistani, it becomes a Paighor when the marriage fails or does not prove successful due to any reason. As the 30 years old respondent Sattar Khan says, "The worse thing of a marriage of refugee and local Pakistani is when there develops a Paighor. Everyone is afraid of marriage with locals is not successful then it will become a source of teasing them. People use such failed marriages as an example in their conversation. When one thing becomes Paighor then it sticks to the person for a long time. People laugh and make fun of such a person. They say he wanted to change his own identity and got married to strangers (Pakistani), now look what is his position." The Paighor becomes part of the family's reputation as it is not limited to that individual but affects all the members who were part of the marriage. The decision-making power in Afghan refugee's marriages lies with family, not individuals. It is the family who decides whom to marry and who not. So, the failure of any marriage brings Paighor for the whole family (and even to clan) and such family is presented as a sample for restricting marriages with locals. Just as respondent Jan Muhammad Aka, who belongs to the Tarakai clan, says; "marriage of one of my daughters with local Pakistani boy has become a problem for my whole family. My daughter's marriage was not successful. It broke up in just two years after marriage. My daughter tried her level best of toleration but all in vain. After the failure of this marriage, the people of my clan came to me. They said that I have brought Paighor for the whole Tarakai. They remind me about their unwillingness at the time when this marriage was decided. At last, I promised them that I would not marry my other three daughters outside my clan. This one incident has affected the life of my whole family. I have to live with this Paighor for the rest of my life." For Afghan refugees failed case of marriage becomes Paighor and as an example for discouraging them from building marriage relations with Pakistani locals.

\section{The Concept of Pilar-Au-Nikah (father and grandfather reputation)}

Pilar-Au-Nikah word means 'father and grandfather', or 'ancestors" reputations. In Afghan society, there is a deeper meaning of this pair of words. It is the source of recognizing or knowing someone by his lineage or clan. The concept of Pilar-Au-Nikah is used in different social situations by Afghans. It also helps in maintaining social orders in Afghan society and is a common norm of refugee's life as well. People avoid acts that can put blame or any mark on their Pilar-Ao-Nikah's reputation. A person uses his Pilar-Au-Nikah's good reputation with pride and honor. Whose Pilar-Au-Nikah's reputation is not good or had a socially negative mark, they hide their identity in the society. 'Such people desire to settle in areas where fewer people know their Pilar-Au-Nikah' according to Karim (respondent).

The concept of 'Pilar-Au-Nikah' means the familiarity of the ancestral background of an individual in tribal society. In this process a complete ancestral background of an individual. Afghans usually possess the knowledge of each other ancestors' background up to four generations (a feature of 
tribal-based society). For almost four generations the lineage is traced back in the marriage process. Which is the case of locals - even with same ethnic groups - is just one or for most of two generations and it discourages any marital relationship between them? The factor of knowing the ancestral background of an individual (Pilar-Au-Nikah) puts weight on marriages with their people (even if they are residing across the border). Those with any negative points - such as any myth of timidity (cowardly) or that of socially considered polluted familial occupation etc.-in their lineage are not preferred choice. In a tribal system, every person knows another because of the lineage systemwhere a total family tree is ideally remembered from generation to generation. It is the reason that Afghan refugees prefer to marry within their group. Pilar-Au-Nikah concept plays an important role in deciding a marriage proposal. This familiarity with the ancestral background is an emphasized point in the decision making of marriages in Afghan refugees.

In refugee camp marriages different Afghan ethnic groups are involved who are less familiar with one another. Only the concept of one nation, being Afghans, spirals them in marriage relations. Those Afghan refugees who live in Nawan Killi belong to different areas and different sub-tribes from Afghanistan. Even they belong to different Afghan ethnic groups such as Pashtun, Hazara, Tajik, Uzbek, etc. The majority of them were not familiar with each other before the migration to Pakistan. The life of refugee camps and the sense of a single nationhood in exile has shortened gaps between Afghan ethnic groups.

\section{Khapal Watan-Awo-Khapala Khawra (own country and own soil/land)}

The concept of 'Khapal Watan-Awo-Khapala Khawra', enables Afghan refugees to keep in touch with the homeland and produce a strong sense of belonging to a separate land which is their native. Khapal Watan-Awo-Khapala Khawra concept is given strength by the experiences from the interaction from the local community. There are sometimes hostile behaviors of locals towards refugees such as lesser economic opportunities, restricted social relations, restricted movements, marginalized socioeconomic status, treatment of as unwanted guests, verbal and physical discriminations, prejudices etc. Culturally non-acceptance of Afghan refugees - who are living for more than three decades in Pakistan - by the locals to accumulate them in mainstream society brought more fissures between locals and refugees. And the hostile policies of the Pakistan government provides strength to the concept of Khapal Watan-Awo-Khapala Khawra. As a respondent, Jamal said, "I have been trying for the last four years to get an identity as a Pakistani national. I have married a Pakistani girl. I cannot move freely in this country (Pakistan), because I do not have the nationality of this country. By marrying a local girl, I have created problems for myself. Even I hesitate to go to my in-laws because any time police can catch me and put me in jail."

Cross-border marriages become a source of keeping transnational connections. It is the source of keeping the young children familiar with their native identity. It also maintains and strengthens the concept of Khapal Watan-Awo-Khapala Khawra. Cross border marriages provide an opportunity to those individuals, who are born and grown up in Pakistan and did not go to their native country before, to visit and learn more about their ancestral land. Such individuals (who are constrained by their family members to visit Afghanistan due to volatile conditions) always speak in the support of transnational marriages. These marriages provide them with opportunities to visit their native land, to fulfill different cultural marriage ceremonies. Keeping cross border marriages, on prime preference by Afghan refugees, finds its roots in the concept to keep young ones touched to their homeland. It is a common norm of Afghan refugees of Nawan Killi, to prefer marriages with their relatives across the border to maintain their native cultural standards in the young generation. Afghan refugees present arguments for preferring cross border marriages over local marriages and camp marriages, as to save the young generation and keep them in touch with their motherland.

\section{Discussion}

This paper started with the argument that transnationalism studies have marginally researched refugee groups, with exception of few studies on their political activism. Proceeding from recent perspectives in the context of migration studies, which shows that the boundaries may be blurred conceptually between migrants and refugee communities, this paper has tried to use the type of transnational activities more commonly found among economic migrants to study Afghan refugees and their transnational marriages. Building on the work of Glick Schiller and Levett's (2004), this research described the transnational marriage practices of Afghan diaspora in Quetta, Baluchistan - how they position themselves in the host society, and their "ways of being" in the host country, and "ways of 
belonging" to the country of origin. According to Levitt and Glick Schiller, the migrants display their 'belonging' consciously and concretely (2004). In contrast, the behaviors adopted by the refugees rather than their identities, determine their 'ways of being' in the host country. These behavior patterns establish a unique cross-border existential space, which operates in social and cultural dimensions (Levitt and Schiller, 2004). This interlinked space that transect national and cultural boundaries is referred to as a 'transnational social field'.

Marriage Patterns in the South-Asian region fall into two modes, with arranged marriage (in which parents choose the spouse) considered as a traditional model and choosing one's spouse considered more 'modern'. Although transnational marriages are prevalently endogamy in nature, they cannot be simply termed as a 'traditional' pattern. Lievens (1999) notes that these endogamous marriages, in which the bride is 'imported' from the homeland, are continuing well into the third generation of refugees, 'Import' of marriage partners serves to increase the opportunity space of migrants, which is a distinctly 'modern' motive. According to Gernsheim (2007), both men and women are motivated that marriage with a partner from the home country will have an impact on the dynamics of power as perceived by the refugees. Men are concerned that marrying someone from the country of origin will lead to a more 'submissive', 'traditional' partner. Migrant women also prefer husbands from the home country as it increases their power and authority in the relationship. It also serves to decrease the influence the husband's family can have on their decisions.

Intermarriage is seen as a primary means of ascertaining the level of assimilation between migration populations, as it is indicative of the acculturation between the two groups. Assimilation is seen as a complete, one-dimensional movement of minority groups into a larger, more dominant population. On the other hand, integration is suggestive of a more mutually accommodating relationship between migrant (minority) and host (majority) populations.

Perceptions of preference for spouse in Afghan refugees in the selected locale are desired towards cross-border or transnational marriages. This preference for marriages has its roots in different causes. One of the main causes of preference for cross-border or transnational marriages is to maintain cultural purity among young generations. There are other reasons such as economic benefits from cross border marriages, keeping in contact with people of native land, maintaining cultural standards of Pilar-Au-Nikah (Father and grandfather background) are some of those arguments presented in support of cross border marriages. Certain concepts such as Pashtunwali (Pashtun Code of Conduct), Mailmastia (Hospitability), Badal (Revenge), Nanawati (Refuge), Purdah (Seclusion), Path-aw-Nang (honor and courage) etc. determine the world view of an individual as carrier of Afghan culture. Family as the basic institution of learning and socialization and developing the personality of an individual even in exile focuses on these concepts.

The preference of marriages for Afghan refugees can be categorized into three distinctive groups: a) local marriages, b) refugee camp marriages and c) transnational or cross border marriages. Afghan refugees prefer their spouses for marriage from these three types of communities/localities. Preferences of marriages for Afghan refugees depend on the choice of individual, family, and other social factors. Certain social factors such as choice of spouse, economic class status, social status, political status, educational status, familial background etc. guide marriage decision and transnational marriages surpasses others by encompassing these desired factors. Family's role in marriage preference is dominant. The majority of Afghan refugees follow arrange marriage patterns, where the family head or senior members of the family decide spouse selection with consent. Marriages with local Pakistani communities are limited. These limitations are accounted for based on discrimination of locals towards Afghan refugees. Refugees experience limitations in mobility, marginalization, and racism, non-acceptance in the host society, which produce a gap between them (refugees) and the local (host) community. In the words of Majeed (one of the elders) 'Local people did not accept us and they (locals) did their best to produce an environment of uneasy acceptance for us but we had no other place to go back then.' The concept of Paighor (mock or taunt) is one of the dominant features in limiting local or Pakistani marriages among Afghan refugees. Afghan refugees consider a failure of local marriages as a Paighor for the individual and his/her family members. People are afraid of gaining Paighor from marriages with local or with host society. The popular mode of marriages among Afghan refugees of Nawa Killi is between their communities living in Pakistan in case they cannot fulfill cross border marriage. There are certain reasons for which intergroup marriages are preferred to marriages with locals. Easy cultural understandings, equality in social status (status of 
being a refugee for both parties), belonging to the same country, the myth returning to origin (Afghanistan), are some of such reasons that help in preference of marriages with refugees than the local population. The Concept of Pilar-Au-Nikah (father and grandfather reputation) adds to the preference of refugee camp marriages. Afghan refugees attach emphasis on the Pilar-Au-Nikah concept while deciding marriages. It is normally preferred to know one's ancestral background (Pilar$A u$-Nikah) for almost four generations in marriage decisions.

Transnational marriages become a source of cross-border connections between refugees and their relatives living in their homeland (Afghanistan). Comparatively these types of marriages are most preferable to two other categories i.e. local marriages and refugee camp marriages. The main reason for cross-border marriages is keeping pure cultural traits among the displaced diaspora population. Other factors such as economic benefits, the Pilar-Au-Nikah concept or attachment to roots back in the country of origin, opportunities for an individual to visit the native country, etc. contribute to the preference of transnational marriages.

\section{Conclusion}

This article shows that Afghan refugees perform transnational marriages as a source of connection between the host country and home country. Transnational marriages are the most desired form of marriages among Afghan refugees living in Pakistan. There are also economic benefits from transnational marriages. But the main purpose of transnational marriages can be summoned as to keep purity in culture and maintain ties to country of origin. Cross-border marriages limit chances of discrimination and marginalization against Afghan refugees, which is frequently seen in local (Pakistani) marriages. There are certain limitations of physical and social nature that constrain the practice of transnational marriages among Afghan refugees. Indeed, with all difficulties, cross-border or transnational marriages are the most preferred forms of marriages among Afghan refugees.

Besides marriages, there are different other sources of transnational connections (such as telephone calls, transnational economic connections, back and forth visits etc.) enabling Afghan refugees to establish and maintain transnational connections. These transnational connections of Afghan refugees stretch from personal to family and even community level.

Other factors promote cross-border marriages among the Afghan Diaspora such as maintaining cultural purity, economic benefits, Pilar-Au-Nikah concept, and opportunities for a visit to the country of origin, discrimination, and marginalization faced by refugees in receiving context. These factors contribute to the preference of transnational marriages. As Abdul Qahir (key respondent) says; "the first argument that comes in decision of cross border marriage is that it will provide a spouse of own cultural identity. A person who wants to marry a Pakistani spouse first looks at different points from such marriage. For example: What will be his/her status in his in-laws? Which culture children acquire? What will be their identity Pakistani of Afghan origin or something else? Where will his children grow up? When such person cannot find satisfactory answers for these questions, then he/she prefers cross border marriage."

\section{References}

Al-Ali, N., Black, R., \& Koser, K. (2001). Refugees and transnationalism: the experience of Bosnians and Eritreans in Europe. Journal of Ethnic and Migration Studies, 27(4), 615 - 634.

Basch, L., Glick Schiller, N. \& Szanton Blanc, C. (1994) Nations Unbound: Transnational Projects, Postcolonial Predicaments, and Deterritorialized Nation-States. Amsterdam: Gordon \& Breach.

Batrouney, T. (1998). Australia's immigration policies: a loss of consensus. Tokyo: National Institute for Research Advancement.

Centlivres, P. (1988). Les trois pôles de l'identité afghane au Pakistan. L'Homme 28(4), 134-146.

Rostami-Povey, E. (2007). Afghan refugees in Iran, Pakistan, the UK, and the US and life after return: A comparative gender analysis. Iranian Studies, 40(2), 241-261.241-261, DOI: $10.1080 / 00210860701269576$

Fletcher, M. 1999.Migrant settlement: A review of the literature and its relevance to New Zealand. Wellington: New Zealand Immigration Service.

Garcia, R. (2006). Mixed Marriages and Transnational Families in the Intercultural Context: A Case Study of African-Spanish Couples in Catalonia. Journal of Ethnic and Migration Studies, 32(3), 403-433. 
Glick Schiller, Nina, Linda Basch, \& Cristina Szanton-Blanc. 1995. "From Immigrant to Transmigrant: Theorizing Transnational Migration.” Anthropological Quarterly 68 (1): $48-$ 63. doi: $10.2307 / 3317464$.

Government of Pakistan and United Nations High Commissioner for Refugees (UNHCR) 2005 Census of Afghans in Pakistan 2005. http://www.unher. Org/431c7b1a2.html (accessed in Februrary15th, 2019.

Gernsheim, B. E. (2007). Transnational lives, transnational marriages: A review of the evidence from migrant communities in Europe. Global Networks, 7(3), 271-288.

Hanifi, M. J. (2008). Anthropology and the Representations of Recent Migrations from Afghanistan. London: Oxford Press.

International Organization for Migration Afghanistan. (2014). Afghanistan- Migration Profile. Kabul: International Organization for Migration (IOM).

Kivisto, Peter. 2001. Theorizing Transnational Migration: A Critical Review of Current Efforts. Ethnic and Racial Studies 24(4): 549-577

Landolt, P., Autler, L. \& Baires, S. (1999) 'From Hermano Lejano to Hermano Mayor: the dialectics of Salvadoran transnationalism', Ethnic and Racial Studies, 22(2): 290- 315.

Lievens, J. (1999). Family-forming migration from Turkey and Morocco to Belgium: The demand for marriage partners from the countries of origin. International migration review, 33(3), 717744.

Levitt, Peggy, and Nina Glick Schiller.2004. "Conceptualizing Simultaneity: A Transnational Social Field Perspective on Society." International Migration Review 38 (3): 1002-1039. doi:10.1111/j.1747-7379.2004.tb00227.x.

Kunz, E. F. (1981). Exile and Resettlement: Refugee Theory. International Migration Review, 07(2).pp. 51

Miles, R. (1993).Racism after race relations. London: Routledge.

Shami, S. (1996). Transnationalism and Refugee Studies: Rethinking Forced Migration and Identity in the Middle East. Journal of Refugee Studies, 9(1), 3-25.

Stein, B., \& Tomasi, S. (1981). Foreword. International Migration Review, 4(1-2), 5-7.

Nye, Joseph S., and Robert O. Keohane. 1971. Transnational Relations and World Politics: An Introduction. International Organization 25(3).

Vertovec, S. \& Cohen, R. (1999) 'Introduction', in Vertovec, S. and Cohen, R. (Eds) Migration, Diasporas, and Transnationalism. London: Edward Elgar, xiii- xviii.

Vertovec, Steven. 2001. 'Transnationalism and Identity,' in the Journal of Ethnic and Migration Studies 27(4): 573-582. 